\title{
Aggressiveness of Phomopsis longicolla and Other Phomopsis spp. on Soybean
}

\author{
Shuxian Li, United States Department of Agriculture-Agricultural Research Service (USDA-ARS), Crop Genetics \\ Research Unit, Stoneville, MS 38776; Glen L. Hartman, USDA-ARS and Department of Crop Science, University \\ of Illinois, Urbana 61801; and Deborah L. Boykin, USDA-ARS, Mid-South Area Office, Stoneville, MS 38776
}

\begin{abstract}
Li, S., Hartman, G. L., and Boykin, D. L. 2010. Aggressiveness of Phomopsis longicolla and other Phomopsis spp. on soybean. Plant Dis. 94:1035-1040.

Phomopsis seed decay of soybean is a major cause of poor-quality soybean seed. The disease is caused primarily by the fungal pathogen Phomopsis longicolla. Aggressiveness of isolates of $P$. longicolla from soybean and other Phomopsis spp. from other hosts were compared by inoculating 2-week-old soybean plants of cv. Williams 82 . There were significant $(P \leq 0.0001)$ differences among isolates based on stem length and stem lesion length. The $P$. longicolla soybean isolate PL16, from Mississippi, caused the shortest stem length while the non-soybean isolate P9, from Illinois, caused the greatest stem lesion length. The type isolate of $P$. longicolla, PL31 (Fau 600), was one of the 3 most aggressive isolates among all 48 isolates tested. The velvetleaf isolate P9 was the most aggressive among 13 isolates from non-soybean hosts. This study provided the first evaluation of aggressiveness of $P$. longicolla isolates from different geographic origins and the first demonstration that Phomopsis spp. isolated from cantaloupe, eggplant, and watermelon infected soybean. Knowledge about the variability of the pathogen is important for selecting isolates for breeding soybean lines with broad-based resistance to Phomopsis seed decay.
\end{abstract}

Phomopsis longicolla Hobbs is the primary cause of Phomopsis seed decay (PSD) in soybean (Glycine max (L.) Merrill). The pathogen was first identified in 1985 (8). Soybean seed infected by $P$. longicolla or other Phomopsis spp. range from symptomless to shriveled, elongated, and cracked, and often appear chalkywhite. Infected seed may not germinate or are slow to germinate. Seed infection causes pre- and post-emergence dampingoff and, under severe conditions, stands can be reduced to the point of reducing yield $(15,22)$.

PSD can affect soybean seed quality due to the reduction of seed viability, oil content, alteration of seed composition, and increase of moldy or split beans $(7,26,27)$ causing potential docking at the point of sale. Hot and high-humidity environments, especially during pod fill to harvest, favor pathogen growth and disease development

Corresponding author: $\mathrm{S}$. Li

E-mail: shuxian.li@ars.usda.gov

Trade and manufacturers names are necessary to report factually on available data; however, the USDA neither guarantees nor warrants the standard of the product, and the use of the name by the USDA implies no approval of the product to the exclusion of others that may also be suitable.

Accepted for publication 19 April 2010.

doi:10.1094/PDIS-94-8-1035

This article is in the public domain and not copyrightable. It may be freely reprinted with customary crediting of the source. The American Phytopathological Society, 2010.
$(3,19,20)$. Infection of soybean seed with $P$. longicolla has resulted in significant economic losses $(2,7)$. Losses on a worldwide basis were about 0.19 million metric tons (MMT) in 1994. Effects of PSD on yields in the United States from 1996 to 2007 ranged from 0.43 to 0.38 MMT (25).

Suggested management strategies for this disease include rotating soybean with nonlegume nonhost crops, applying fungicides during pod-fill, and tilling the soil to disrupt spore dissemination (6). Along with these strategies, the use of resistant cultivars may provide control of PSD $(9,10,16,17)$, especially when environmental conditions are conducive for disease development. However, development of resistant cultivars may depend on the variability of the pathogen, including isolate aggressiveness. The term "pathogen aggressiveness," as defined in our study, is based on colonization of and damage to soybean $(1,21)$.

Little is known about the variability of aggressiveness on soybean among $P$. longicolla isolates from different geographic origins. Isolates of $P$. longicolla and other Phomopsis spp. from weeds have been reported to cause disease in soybean $(1,14)$; however, isolate differences based on pathogenicity tests were only reported for a limited number of isolates (three Phomopsis spp. and three $P$. longicolla isolates) infecting soybean (14). Information about the aggressiveness of Phomopsis spp. isolates from other non-soybean hosts that infect soybean is also lacking. More detailed knowledge about the variability of the pathogen is essential for un- derstanding the population, and such information will also be important for selecting isolates to develop broad-based PSD-resistant soybean lines. The objective of this study was to measure the aggressiveness of $P$. longicolla and other Phomopsis spp. isolates from soybean and non-soybean hosts based on inoculations under greenhouse conditions.

\section{MATERIALS AND METHODS}

Fungal cultures and inoculum preparation. In total, 48 isolates from the $\mathrm{Na}$ tional Soybean Pathogen Collection Center at the University of Illinois at UrbanaChampaign were evaluated in this study. These included $35 P$. longicolla isolates from soybean in eight states in the United States, two $P$. longicolla isolates from velvetleaf in Illinois (11), and 11 other Phomopsis spp. isolates from other hosts in four states in the United States, as well as Canada and Costa Rica (Table 1). Isolate PL31 (Fau 600, American Type Culture Collection no. 64802) from soybean in Ohio was the type culture of $P$. longicolla (8). Each isolate of $P$. longicolla was examined for sporulation, dimension of conidia, pattern of stroma, and presence or absence of hyaline, filiform, and hamate $\beta$ conidia and perithecia to confirm identification (6). The identifications of soybean isolates were verified previously by sequence analysis of the internal transcribed spacer (ITS) regions and the mitochondrial small-subunit rRNA genes $(11,30)$. The identity of 11 other Phomopsis spp. isolates from other hosts was confirmed by the United States Department of Agriculture-Agricultural Research Service Systematic Botany and Mycology Laboratory, Beltsville, MD (http://nt.ars-grin.gov/fun galdatabases/specimens/specimens.cfm). The fungal cultures were maintained on $2 \%$ water agar plates at $4^{\circ} \mathrm{C}$ or stored in liquid nitrogen or in $15 \%$ glycerol at $-80^{\circ} \mathrm{C}$ in a cryogenic freezer.

For greenhouse tests, all isolates on water agar or in cryogenic storage were transferred to acidified potato dextrose agar (APDA). To purify cultures, a $100-\mu \mathrm{l}$ diluted spore suspension of each isolate was spread on acidified water agar $(\mathrm{pH} 5.5)$ and single spores were isolated with a fine needle under an Olympus SZX12 dissecting microscope and then transferred to APDA. The fresh single-spored cultures were incubated at $24^{\circ} \mathrm{C}$ under 12-h-per day fluorescent light for 10 to 12 days and then used to inoculate plants. 
Plant inoculation. Soybean seed of a susceptible cultivar, Williams 82 (obtained from Illinois, Crop Improvement Inc., Champaign, IL) was used each experiment in this study. Prior to planting for each experiment, 100 randomly selected Williams 82 seeds were disinfested in $0.25 \%$ $\mathrm{NaOCl}$ for $60 \mathrm{~s}$, rinsed with distilled water, blotted, and placed on APDA, then incubated for 5 days at $24^{\circ} \mathrm{C}$ to evaluate germination and to determine the incidence of $P$. longicolla. Seed used for each experiment had no incidence of $P$. longicolla. Seed were sown in Ray Leach Cone-
Tainers (Stuewe \& Sons, Inc., Corvallis, OR) at one seed per Cone-Tainer in an autoclaved soil:sand $\operatorname{mix}(1: 1, \mathrm{vol} / \mathrm{vol})$ at $\mathrm{pH}$ 7.0. The soil used was Sun Grow Metro Mix 360 (Sun Grow Horticulture Products, Belleview, WA). Cone-Tainers were placed in racks on a greenhouse bench under a 14-h photoperiod with a light intensity of $434 \mu \mathrm{Em}^{-2} \mathrm{~s}^{-1}$ at $25 \pm 2{ }^{\circ} \mathrm{C}$ and watered daily.

Mycelial plugs (4 $\mathrm{mm}$ in diameter) from the margin of a 10-day-old culture on APDA were punched out with the large ends of disposable micropipette tips (200 $\mu \mathrm{l})$. The micropipette tip containing the fungal mycelium was subsequently placed over a 2-week-old cut soybean stem that was cut at just below the first trifoliate node. Micropipette tips containing plugs of noninfested APDA served as the negative control. Two days after inoculation, micropipette tips were removed. At 7 days after inoculation, the main stem length was measured from the soil line to the top of the plant and the lesion on the stem was measured. The experiment was a randomized complete block design with three replications and there were three plants per isolate in each

Table 1. Phomopsis longicolla and Phomopsis spp. isolates used to evaluate aggressiveness and their hosts and geographic origins

\begin{tabular}{|c|c|c|c|c|}
\hline Fungal species & Host (common name) & Host (scientific name) & Geographic origin & No. of isolates \\
\hline Phomopsis longicolla & Soybean & Glycine $\max$ & Arkansas & 4 \\
\hline P. longicolla & Soybean & G. $\max$ & Illinois & 5 \\
\hline P. longicolla & Soybean & G. $\max$ & Iowa & 3 \\
\hline P. longicolla & Soybean & G. $\max$ & Mississippi & 12 \\
\hline P. longicolla & Soybean & G. $\max$ & Missouri & 3 \\
\hline P. longicolla & Soybean & G. $\max$ & Nebraska & 3 \\
\hline P. longicolla & Soybean & G. $\max$ & Ohio & 1 \\
\hline P. longicolla & Soybean & G. $\max$ & Wisconsin & 4 \\
\hline P. longicolla & Velvetleaf & Abutilon theophrasti & Illinois & 2 \\
\hline P. melonis & Melon & Cucumis melo & Texas & 2 \\
\hline P. melonis & Melon & C. melo & Oklahoma & 1 \\
\hline Phomopsis spp. & Bindweed & Convolvulus arvensis & Canada & 1 \\
\hline Phomopsis spp. & Cantaloupe & Cucumis melo subsp. melo var. cantalupensis & Costa Rica & 1 \\
\hline Phomopsis spp. & Cantaloupe & C. melo subsp. melo var. cantalupensis & Oklahoma & 1 \\
\hline Phomopsis spp. & Cantaloupe & C. melo subsp. melo var. cantalupensis & Texas & 1 \\
\hline Phomopsis spp. & Eggplant & Solanum melongena & Oklahoma & 1 \\
\hline Phomopsis spp. & Watermelon & Citrullus lanatus var. lanatus & Costa Rica & 1 \\
\hline Phomopsis spp. & Watermelon & C. lanatus var. lanatus & Oklahoma & 1 \\
\hline Diaporthe phaseolorum & $\ldots$ & Stokesia laevis & Mississippi & 1 \\
\hline Total number & $\ldots$ & $\ldots$ & $\ldots$ & 48 \\
\hline
\end{tabular}

Table 2. Mixed model analysis of variance of stem length of soybean cv. Williams 82 after inoculation with 48 Phomopsis longicolla and Phomopsis spp. isolates for 7 days in three replicated trials under greenhouse conditions

\begin{tabular}{|c|c|c|c|c|c|c|}
\hline Source of variance for stem length $\mathrm{v}$ & Species $^{w}$ & Origin & $\mathbf{D F}^{\mathbf{x}}$ & $\boldsymbol{F}$ & $P \geq F$ & Estimated variance components ${ }^{y}$ \\
\hline \multicolumn{7}{|l|}{ Fixed effects } \\
\hline Isolate & $\ldots$ & $\ldots$ & 47 & 29.01 & $<0.0001$ & $\ldots$ \\
\hline Species & $\ldots$ & $\ldots$ & 1 & 27.98 & $<0.0001$ & $\ldots$ \\
\hline \multicolumn{7}{|l|}{ Origins within species } \\
\hline & $\mathrm{P}$ & $\ldots$ & 4 & 63.08 & $<0.0001$ & $\ldots$ \\
\hline \multirow{2}{*}{\multicolumn{7}{|c|}{ Isolates within species and origins }} \\
\hline & & & & & & \\
\hline & $\mathrm{P}$ & Canada $^{z}$ & $\cdots$ & & & $\ldots$ \\
\hline & $\mathrm{P}$ & Costa Rica & 1 & 53.14 & $<0.0001$ & $\ldots$ \\
\hline & $\mathrm{P}$ & Mississippi $^{\mathrm{z}}$ & $\ldots$ & $\ldots$ & $\ldots$ & $\ldots$ \\
\hline & $\mathrm{P}$ & Oklahoma & 3 & 7.82 & $<0.0001$ & $\ldots$ \\
\hline & $\mathrm{P}$ & Texas & 2 & 0.25 & 0.7793 & $\ldots$ \\
\hline & PL & Arkansas & 3 & 23.72 & $<0.0001$ & $\ldots$ \\
\hline & PL & Illinois & 6 & 37.36 & $<0.0001$ & $\ldots$ \\
\hline & PL & Iowa & 2 & 1.19 & 0.3051 & $\ldots$ \\
\hline & PL & Missouri & 2 & 6.54 & 0.0016 & $\ldots$ \\
\hline & PL & Missouri & 11 & 7.20 & $<0.0001$ & $\ldots$ \\
\hline & PL & Nebraska & 2 & 8.17 & 0.0003 & $\ldots$ \\
\hline & PL & Ohio $^{z}$ & $\ldots$ & $\ldots$ & $\ldots$ & $\ldots$ \\
\hline & PL & Wisconsin & 3 & 5.20 & 0.0016 & $\ldots$ \\
\hline \multicolumn{7}{|l|}{ Random effects } \\
\hline Trial & $\ldots$ & $\ldots$ & $\ldots$ & $\ldots$ & $\ldots$ & 0.0000 \\
\hline Replication $\times$ trial & $\ldots$ & $\ldots$ & $\ldots$ & $\ldots$ & $\ldots$ & 1.4160 \\
\hline Trial $\times$ isolate & $\ldots$ & $\ldots$ & $\ldots$ & $\ldots$ & $\ldots$ & 0.0000 \\
\hline Residual & $\ldots$ & $\ldots$ & $\ldots$ & $\ldots$ & $\ldots$ & 49.5898 \\
\hline
\end{tabular}

${ }^{\mathrm{v}}$ Stem length was calculated as percentage of the negative control without fungal inoculation.

${ }^{\mathrm{w}} \mathrm{P}=$ Phomopsis spp. Isolates and $\mathrm{PL}=$ Phomopsis longicolla isolates.

${ }^{\mathrm{x}}$ Numerator degree of freedom. The denominator degree of freedom (DF) is 376 (not shown in the table) for all $F$ tests. The DF was calculated based on Kendword and Rogers approximation method (12).

${ }^{\mathrm{y}}$ Negative variance components are set to zero based on restricted maximum likelihood estimation (12).

${ }^{z}$ Only one isolate. 
replication. The experiment consisted of three greenhouse trials, which started in November 2005 and ended in May 2006.

Data analysis. Analysis of variance (ANOVA) using the mixed procedure (PROC MIXED) of SAS (version 9.2; SAS Institute, Cary, NC) was performed. Data were averaged across the three subsamples for each experimental unit. For the ANOVA, trial and trial-isolate were random effects. The fixed effects of isolate were partitioned in the ANOVA table based on the following set of orthogonal contrasts: species ( $P$. longicolla and Phomopsis spp.), geographic origin differences within species, isolate differences within each geographic origin, and species. Mean comparisons were based on least significant difference at $P \leq 0.05$. The PROC CORR procedure of SAS was used to compute Pearson's correlation coefficients between the mean of variables with the formulas stem length $=$ (stem length of plant inoculated with fungal pathogen/stem length of plants treated with pathogen-free APDA) $\times 100 \%$ and stem lesion length $=$ (stem lesion length/stem length of plant) $\times$ $100 \%$.

\section{RESULTS}

Results of ANOVA showed that the trial-isolate was not an important source of variation for either variable (Tables 2 and 3 ); therefore, isolate means were averaged over trials (Tables 4 and 5).

In this study, because the stem was excised below the first trifoliate, stems gen- erally did not grow. However, the stems of the control plants remained green while inoculated stems appeared to have shorter lengths due to the infection. Some isolates caused stems to dry out or die faster than other isolates. For the stem length, differences among $P$. longicolla isolates within the same geographic origin were greater than other Phomopsis spp. isolates (Table 2). For $P$. longicolla, isolates from Illinois had the greatest $F$ value of 37.4 followed by isolates from Arkansas $(F=23.7)$. There was no significant difference $(P=$ 0.3051 ) among three isolates from Iowa (Table 2). The mean value of stem length as the percentage of the control plants without fungal inoculation was $40.2 \%$. The soybean isolate, P. longicolla PL16 from Mississippi, caused the lowest stem length (46.7\%), followed by $47.3 \%$ for the type isolate PL31 (Table 4). Isolates P6 and P5 of the Phomopsis spp. and P. longicolla PL3 resulted in the greatest stem lengths of $88.4,83.7$, and 87.2, respectively (Tables 4 and 5).

For the stem lesion length, all P. longicolla and other Phomopsis spp. isolates caused stem lesions on soybean Williams 82, whereas the negative control using APDA did not. Differences among $P$. longicolla isolates within the same geographic origin were smaller than other Phomopsis spp. isolates (Table 3). For $P$. longicolla, isolates from Illinois had the greatest $F$ value (39.9) followed by isolates from Arkansas $(F=35.9)$, while isolates from Iowa had the lowest $F$ value (Table
3 ). The stem lesion length as a percentage of the stem length ranged from 6.6 to $71 \%$ (Tables 4 and 5). Isolates P9, PL20, PL31, and P11 had the greatest lesion length, with values of $71.0,67.6,64.6$, and $64.6 \%$, respectively (Tables 4 and 5).

Based on stem length and lesion length, the type isolate of $P$. longicolla, PL31, was one of the 3 most aggressive isolates among all 48 isolates tested. The velvetleaf isolate P9 from Illinois was the most aggressive among 13 isolates (11 Phomopsis spp. and 2 P. longicolla isolates) from nonsoybean hosts. Using Pearson's correlation analysis, stem length and stem lesion length were significantly $(P \leq 0.0001)$ negatively correlated, with a correlation coefficient of 0.8 .

\section{DISCUSSION}

The members of the DiaporthePhomopsis complex consist of $P$. longicolla (the primary cause of PSD) and three varieties of Diaporthe phaseolorum (Cooke \& Ellis) Sacc. (anamorph P. phaseoli (Desm.) Sacc.), in which $D$. phaseolorum var. caulivora Athow \& Caldwell, and D. phaseolorum var. meridionalis F.A. Fernández cause stem canker of soybean while $D$. phaseolorum var. sojae (Lehman) Wehm. causes pod and stem blight (23). The Diaporthe-Phomopsis complex is distributed worldwide and causes more losses in soybean than any other single fungal pathogen (23). P. longicolla differs from other species in the Diaporthe-Phomopsis complex in its morphology (it does not have a

Table 3. Mixed model analysis of variance of stem lesion lengths on soybean cv. Williams 82 after inoculation with 48 Phomopsis longicolla and Phomopsis spp. isolates for 7 days

\begin{tabular}{|c|c|c|c|c|c|c|}
\hline Source of variance for lesion length $\mathrm{v}$ & Species $^{w}$ & Origin & $\mathbf{D F}^{\mathrm{x}}$ & $\boldsymbol{F}$ & $P \geq F$ & Estimated variance components ${ }^{y}$ \\
\hline \multicolumn{7}{|l|}{ Fixed effects } \\
\hline Isolate & $\ldots$ & $\ldots$ & 47 & 25.48 & $2 \mathrm{E}-37$ & $\ldots$ \\
\hline Species & $\ldots$ & $\ldots$ & 1 & 9.77 & $2 \mathrm{E}-03$ & $\ldots$ \\
\hline \multicolumn{7}{|l|}{ Origins within species } \\
\hline & $\mathrm{P}$ & $\ldots$ & 4 & 84.86 & $1 \mathrm{E}-30$ & $\ldots$ \\
\hline & PL & $\ldots$ & 7 & 38.92 & $3 \mathrm{E}-25$ & $\ldots$ \\
\hline \multicolumn{7}{|l|}{ Isolates within species and origins } \\
\hline & $\mathrm{P}$ & Canada ${ }^{z}$ & $\ldots$ & & ... & $\ldots$ \\
\hline & $\mathrm{P}$ & Costa Rica ${ }^{\mathrm{z}}$ & 1 & 44.29 & 2E-09 & $\ldots$ \\
\hline & $\mathrm{P}$ & Mississippi & $\ldots$ & & $\ldots$ & $\ldots$ \\
\hline & $\mathrm{P}$ & Oklahoma & 3 & 7.28 & $2 \mathrm{E}-04$ & $\ldots$ \\
\hline & $\mathrm{P}$ & Texas & 2 & 1.62 & $2 \mathrm{E}-01$ & $\ldots$ \\
\hline & PL & Arkansas & 3 & 35.92 & $1 \mathrm{E}-15$ & $\ldots$ \\
\hline & PL & Illinois & 6 & 39.90 & $6 \mathrm{E}-24$ & $\ldots$ \\
\hline & PL & Iowa & 2 & 1.68 & 2E-01 & $\ldots$ \\
\hline & PL & Missouri & 2 & 11.80 & $3 \mathrm{E}-05$ & $\ldots$ \\
\hline & PL & Mississippi & 11 & 5.01 & $4 \mathrm{E}-06$ & $\ldots$ \\
\hline & PL & Nebraska & 2 & 23.52 & $5 \mathrm{E}-09$ & $\ldots$ \\
\hline & PL & Ohio $^{\mathrm{z}}$ & $\ldots$ & & 年 & $\ldots$ \\
\hline & PL & Wisconsin & 3 & 11.77 & $1 \mathrm{E}-06$ & $\ldots$ \\
\hline \multicolumn{7}{|l|}{ Random effects } \\
\hline Trial & $\ldots$ & $\ldots$ & $\ldots$ & $\ldots$ & $\ldots$ & 0.0000 \\
\hline Replication $\times$ trial & $\ldots$ & $\ldots$ & $\ldots$ & $\ldots$ & $\ldots$ & 0.9281 \\
\hline Trial $\times$ isolate & $\ldots$ & $\ldots$ & $\ldots$ & $\ldots$ & $\ldots$ & 23.7779 \\
\hline Residual & $\ldots$ & $\ldots$ & $\ldots$ & $\ldots$ & $\ldots$ & 24.7058 \\
\hline
\end{tabular}

${ }^{\mathrm{v}}$ Stem lesion length was calculated as the percentage of the stem length in three replicated trials under greenhouse conditions.

${ }^{\mathrm{w}} \mathrm{P}=$ Phomopsis spp. Isolates and $\mathrm{PL}=$ Phomopsis longicolla isolates.

${ }^{\mathrm{x}}$ Numerator degree of freedom. The denominator degree of freedom (DF) is 96 (not shown in the table) for all $F$ tests. The DF was calculated based on Kendword and Rogers approximation method (12).

${ }^{\mathrm{y}}$ Negative variance components are set to zero based on restricted maximum likelihood estimation (12).

${ }^{z}$ Only one isolate. 
Table 4. Mean percent stem lengths based on the noninoculated control and percent lesion lengths based on the stem length of soybean cv. Williams 82 for 35 soybean isolates of Phomopsis longicolla 7 days after inoculation

\begin{tabular}{|c|c|c|c|c|c|}
\hline Isolate $^{w}$ & $\begin{array}{c}\text { Alternate } \\
\text { code, name }\end{array}$ & $\begin{array}{c}\text { Geographic } \\
\text { origin }\end{array}$ & $\begin{array}{l}\text { Year isolated } \\
\text { or acquired }\end{array}$ & $\begin{array}{c}\text { Stem } \\
\text { lengthy }\end{array}$ & $\begin{array}{c}\text { Lesion } \\
\text { length }\end{array}$ \\
\hline PL1 & AK 1 & Arkansas & 2002 & 69.3 efghi & $47.4 \mathrm{fg}$ \\
\hline PL2 & $\mathrm{AK} 2$ & Arkansas & 2002 & $59.6 \mathrm{klm}$ & $47.9 \mathrm{fg}$ \\
\hline PL3 & AK 3 & Arkansas & 2002 & $87.2 \mathrm{a}$ & $6.6 \mathrm{t}$ \\
\hline PL4 & $\mathrm{AK} 4$ & Arkansas & 2002 & 72.0 defgh & $40.0 \mathrm{jkl}$ \\
\hline PL5 & IL1 & Illinois & 2002 & 50.5 nop & $63.3 \mathrm{ab}$ \\
\hline PL6 & IL2 & Illinois & 2002 & 75.9 bcde & 32.5 no \\
\hline PL7 & IL3 & Illinois & 2002 & $79.5 \mathrm{bc}$ & $33.6 \mathrm{mno}$ \\
\hline PL8 & IL4 & Illinois & 2002 & $79.9 \mathrm{abc}$ & $29.5 \mathrm{opq}$ \\
\hline PL9 & IL5 & Illinois & 2002 & $81.4 \mathrm{ab}$ & $12.0 \mathrm{~s}$ \\
\hline PL10 & IO1 & Iowa & 2002 & 76.0 bcde & 31.0 nop \\
\hline PL11 & $\mathrm{IO} 2$ & Iowa & 2002 & $79.7 \mathrm{bc}$ & $27.1 \mathrm{pqr}$ \\
\hline PL12 & IO3 & Iowa & 2002 & 74.8 bcdef & $35.5 \mathrm{lmn}$ \\
\hline PL13 & MS1 & Mississippi & 2006 & 65.6 hijk & $45.8 \mathrm{ghi}$ \\
\hline PL14 & MS2 & Mississippi & 2006 & $61.4 \mathrm{jkl}$ & 44.1 ghij \\
\hline PL15 & MS3 & Mississippi & 2006 & $61.5 \mathrm{jkl}$ & $45.1 \mathrm{ghi}$ \\
\hline PL16 & MS4 & Mississippi & 2006 & $46.7 \mathrm{p}$ & $53.5 \mathrm{de}$ \\
\hline PL17 & MS5 & Mississippi & 2006 & $55.0 \mathrm{lmn}$ & $46.8 \mathrm{fgh}$ \\
\hline PL18 & MS6 & Mississippi & 2006 & $62.7 \mathrm{ijk}$ & 43.2 ghijk \\
\hline PL19 & MS7 & Mississippi & 2006 & 50.7 nop & $56.5 \mathrm{~cd}$ \\
\hline PL20 & MS8 & Mississippi & 2006 & 47.8 nop & $67.6 \mathrm{a}$ \\
\hline PL21 & MS9 & Mississippi & 2006 & 52.7 mnop & $47.7 \mathrm{fg}$ \\
\hline PL22 & MS10 & Mississippi & 2006 & 51.9 nop & $51.0 \mathrm{ef}$ \\
\hline PL23 & MS11 & Mississippi & 2006 & $54.5 \mathrm{lmno}$ & $47.5 \mathrm{fg}$ \\
\hline PL24 & MS12 & Mississippi & 2006 & 49.9 nop & $59.1 \mathrm{bc}$ \\
\hline PL25 & MO1 & Missouri & 2002 & 68.3 fghij & $46.7 \mathrm{fgh}$ \\
\hline PL26 & $\mathrm{MO} 2$ & Missouri & 2002 & $80.3 \mathrm{abc}$ & $24.5 \mathrm{qr}$ \\
\hline PL27 & MO3 & Missouri & 2002 & 73.6 cdefg & $38.4 \mathrm{klm}$ \\
\hline PL28 & NB1 & Nebraska & 2002 & $81.4 \mathrm{ab}$ & $10.6 \mathrm{st}$ \\
\hline PL29 & NB2 & Nebraska & 2002 & 80.0 abc & 32.4 no \\
\hline PL30 & NB3 & Nebraska & 2002 & 69.1 efghi & $41.4 \mathrm{ijk}$ \\
\hline PL31 & Fau 600 & Ohio & 2001 & 47.3 op & $64.6 \mathrm{a}$ \\
\hline PL32 & WI1 & Wisconsin & 2003 & 78.9 bcd & $24.1 \mathrm{r}$ \\
\hline PL33 & WI2 & Wisconsin & 2003 & 67.1 ghij & 43.8 ghij \\
\hline PL34 & WI3 & Wisconsin & 2003 & 76.3 bcde & $23.0 \mathrm{r}$ \\
\hline PL35 & WI4 & Wisconsin & 2003 & $70.8 \mathrm{efgh}$ & 42.0 hijk \\
\hline Mean & $\ldots$ & $\ldots$ & $\ldots$ & 66.8 & 40.2 \\
\hline
\end{tabular}

${ }^{w}$ Isolate codes were designated at the National Soybean Pathogen Collection Center, University of Illinois at Urbana-Champaign. Isolates from Arkansas and Ohio were provided by Dr. J. Rupe and Dr. A. Rossman, respectively; isolates from Illinois, Iowa. Missouri, Mississippi, Nebraska, and Wisconsin were collected or isolated by Dr. S. Li and Dr. G. Hartman.

${ }^{x}$ Alternative code or name either was designated before establishing the culture database at the National Soybean Pathogen Collection Center, University of Illinois at Urbana-Champaign or this was the original culture name when received or isolated.

y Stem length $=$ (stem length of plant inoculated with fungal pathogen/stem length of plants treated with pathogen-free acidified potato dextrose agar) $\times 100 \%$ based on three replicated trials under greenhouse conditions. Means followed by the same letter are not significantly different by the least significant difference test $(P=0.05)$

${ }^{\mathrm{z}}$ Stem lesion length $=($ stem lesion length/stem length of plant $) \times 100 \%$ based on three replicated trials under greenhouse conditions. Means followed by the same letter are not significantly different by the least significant difference test $(P=0.05)$.

known teleomorph) and causation (8). Although other Diaporthe and Phomopsis spp. may be associated with PSD, the disease is primarily caused by $P$. longicolla (23). $P$. longicolla was reported as the predominant species isolated from diseased plants collected from nine locations over a 3-year period in Canada (28). In another study, $P$. longicolla was the most frequently isolated fungal pathogen from both discolored and nondiscolored mature soybean stems (5). It was also reported that $P$. longicolla was the major fungal species with the highest isolation frequency from all vegetative plant parts, pods, and seed in hot and humid environments over a 3-year period (13).

Along with the wide distribution and high occurrence of the pathogen in soy- be beneficial in reducing sources of inoculum.

There have been few molecular and pathogenicity studies on $P$. longicolla. Zhang et al. (29) developed primers made to the conserved sequences of nuclear ribosomal DNA that amplified the ITS region of $D$. phaseolorum and $P$. longicolla, leading to a detection method to distinguish these pathogens from each other and from other soybean fungal pathogens (29). For P. longicolla, no differences were found in ITS sequences of seven geographically diverse isolates (30). In a recent pathogenicity test (14), soybean pods inoculated at growth stage R7 with two $P$. longicolla isolates from weeds showed 25 to $30 \%$ infection of seed, while one soybean isolate caused seed infection of $80 \%$. That study used only a few isolates but showed that there were differences in aggressiveness. This was further confirmed in our study, where aggressiveness of $P$. longicolla isolates from different geographic origins and other Phomopsis spp. isolates from non-soybean hosts that infect soybean showed a large range in aggressiveness.

In this study, 48 isolates were evaluated under greenhouse conditions. The type isolate of P. longicolla, PL31 (Fau 600), was one of the 3 most aggressive isolates among all 48 isolates tested. The velvetleaf isolate P9 from Illinois was the most aggressive among 13 isolates from nonsoybean hosts and caused the greatest stem lesion length among all isolates tested in this study. DNA of the mitochondrial small-subunit rRNA genes of the two velvetleaf isolates (P8 and P9) from Illinois were previously sequenced and the sequences were identical to those from the soybean isolates of $P$. longicolla (11); however, the velvetleaf isolate P8 was not as aggressive compared with the other velvetleaf isolate P9. It appears that the particular DNA of these two isolates sequenced was not associated with the aggressiveness of the isolates.

Based on stem length, there were significant $(P \leq 0.001)$ differences among isolates from most states, except for three $P$. longicolla isolates from Iowa $(P=0.3051)$ and two isolates from Texas $(P=0.7793)$. Isolates from different states were also significantly $(P \leq 0.001)$ different based on the stem lesion length. The three soybean $P$. longicolla isolates (PL20, PL31, and PL5) causing the greatest stem lesion length were from Mississippi, Ohio, and Illinois, respectively, while three soybean $P$. longicolla isolates (PL3, PL28, and PL9) causing the shortest stem lesion length were from $\mathrm{Ar}$ kansas, Nebraska, and Illinois, respectively. More isolates from different geographic origins are needed for testing to determine whether there is association between geographic origin and aggressiveness.

Although $P$. longicolla is primarily known as a seedborne pathogen, it can be 
Table 5. Mean percent stem lengths based on the noninoculated control and percent lesion lengths based on the stem length of soybean cv. Williams 82 for 13 non-soybean Phomopsis spp. 7 days after inoculation

\begin{tabular}{|c|c|c|c|c|c|c|}
\hline Isolate $^{w}$ & $\begin{array}{c}\text { Alternate code, } \\
\text { name }^{\mathrm{x}}\end{array}$ & $\begin{array}{c}\text { Host } \\
\text { (common name) }\end{array}$ & $\begin{array}{c}\text { Host } \\
\text { (scientific name) }\end{array}$ & $\begin{array}{c}\text { Geographic } \\
\text { origin }\end{array}$ & $\begin{array}{l}\text { Stem } \\
\text { length }\end{array}$ & $\begin{array}{l}\text { Lesion } \\
\text { length }^{2}\end{array}$ \\
\hline P1 & CR 98009-1 & Cantaloupe & Cucumis melo subsp. melo var. cantalupensis & Costa Rica & $55.1 \mathrm{ef}$ & $63.5 \mathrm{bc}$ \\
\hline $\mathrm{P} 2$ & CR 990009-3 & Watermelon & Citrullus lanatus var. lanatus & Costa Rica & $79.3 \mathrm{bc}$ & $32.8 \mathrm{~g}$ \\
\hline P3 & Fau 458 & Stokes' aster & Stokesia laevis & Mississippi & $77.1 \mathrm{c}$ & $35.5 \mathrm{f}$ \\
\hline P4 & Fau 640 & Melon & Cucumis melo & Texas & $82.9 \mathrm{~b}$ & $14.2 \mathrm{j}$ \\
\hline P5 & Fau 641 & Melon & C. melo & Texas & $83.7 \mathrm{ab}$ & $17.2 \mathrm{i}$ \\
\hline P6 & Fau 649 & Bindweed & Convolvulus arvensis & Canada & $88.4 \mathrm{a}$ & $9.5 \mathrm{k}$ \\
\hline P7 & Fau 656 & Melon & Cucumis melo & Oklahoma & $58.7 \mathrm{e}$ & $54.8 \mathrm{~d}$ \\
\hline P8 & $\mathrm{i} 250$ & Velvetleaf & Abutilon theophrasti & Illinois & $80.0 \mathrm{bc}$ & $32.0 \mathrm{~g}$ \\
\hline P9 & i251 & Velvetleaf & A. theophrasti & Illinois & $49.7 \mathrm{~g}$ & $71.0 \mathrm{a}$ \\
\hline P10 & OK 1034-2 & Watermelon & Citrullus lanatus var. lanatus & Oklahoma & $67.6 \mathrm{~d}$ & $45.0 \mathrm{e}$ \\
\hline P11 & OK 1054-1 & Eggplant & Solanum melongena & Oklahoma & $52.3 \mathrm{fg}$ & $64.6 \mathrm{~b}$ \\
\hline P12 & OK $1062-6$ & Cantaloupe & Cucumis melo subsp. melo var. cantalupensis & Oklahoma & $55.8 \mathrm{ef}$ & $62.3 \mathrm{c}$ \\
\hline $\mathrm{P} 13$ & TX 1051-1 & Cantaloupe & C. melo subsp. melo var. cantalupensis & Texas & $81.4 \mathrm{bc}$ & $22.4 \mathrm{~h}$ \\
\hline Mean & $\ldots$ & $\ldots$ & $\ldots$ & $\ldots$ & 77.8 & 40.4 \\
\hline
\end{tabular}

${ }^{\mathrm{w}}$ Isolate codes were designated at the National Soybean Pathogen Collection Center, University of Illinois at Urbana-Champaign. All isolates were provided by Dr. A. Rossman except i250 and i251 (Phomopsis longicolla), which were isolated by Dr. S. Li (11).

${ }^{x}$ Alternative code or name either was designated before establishing the culture database at the National Soybean Pathogen Collection Center, University of Illinois at Urbana-Champaign or this was the original culture name when received or isolated.

${ }^{\mathrm{y}}$ Stem length $=$ (stem length of plant inoculated with fungal pathogen/stem length of plants treated with pathogen free acidified potato dextrose agar) $\times$ $100 \%$ based on three replicated trials under greenhouse conditions. Means followed by the same letter are not significantly different by the least significant difference test $(P=0.05)$.

${ }^{\mathrm{z}}$ Stem lesion length $=($ stem lesion length/stem length of plant $) \times 100 \%$ based on three replicated trials under greenhouse conditions. Means followed by the same letter are not significantly different by the least significant difference test $(P=0.05)$.

isolated from all plant parts. Evaluating isolates for aggressiveness based on seedinfecting characteristics may not be a possible or a practical evaluation method, especially when working with many isolates. The cut-seedling assay measuring stem length and stem lesion length under controlled greenhouse conditions is, however, an easy and effective method to compare isolates and provide quantitative measurements of the infection by isolates on soybean. This method was used to test the pathogenicity of $P$. longicolla as a new pathogen on velvetleaf not only in the United States (11) but also in Croatia (24); in addition, it was also used to confirm the first discovery of $P$. longicolla causing soybean stem blight in China (4). Additional studies are under way to characterize the isolates using a real-time quantitative polymerase chain reaction assay to quantify the amount of $P$. longicolla genomic DNA in soybean tissues ( $\mathrm{S}$. Li, unpublished).

This study provided the first evaluation of aggressiveness of $P$. longicolla isolates from different geographic origins and the first demonstration that Phomopsis spp. from cantaloupe, eggplant, and watermelon caused lesions on soybean. Knowledge about the variability of the pathogen is important for selecting isolates for breeding soybean lines with broad-based resistance to $\mathrm{PSD}$.

\section{ACKNOWLEDGMENTS}

We thank C. R. Grau, A. Rossman, and J. Rupe for providing fungal cultures or diseased plant samples; and J. King and C. You for assisting with the pathogenicity tests. This research was partially supported by the United Soybean Board, Illinois Soybean Association, North Central Soybean Research Program, and United States Department of Agriculture-Agricultural Research Service and Cooperative State Research, Education, and Extension Service.

\section{LITERATURE CITED}

1. Agrios, G. N. 1999. Plant Pathology. Academic Press, San Diego, CA.

2. Baird, R. E., Abney, T. S., and Mullinix, B. G. 2001. Fungi associated with pods and seeds during the R6 and R8 stages of four soybean cultivars in southwestern Indiana. Phytoptotection 82:1-11.

3. Balducchi, A. J., and McGee, D. C. 1987. Environmental factors influencing infection of soybean seeds by Phomopsis and Diaporthe species during seed maturation. Plant Dis. 71:209-212.

4. Cui, Y. L. Duan, C. X., Wang, X. M., Li, H.J., and Zhu, Z. D. 2009. First report of Phomopsis longicolla causing soybean stem blight in China. Plant Pathol. 58:799.

5. Harrington, T. C., Steimel, J., Workneh, F., and Yang, X. B. 2000. Molecular identification of fungi with vascular discoloration of soybean in the north central United States. Plant Dis. 84:83-89.

6. Hartman, G. L., Sinclair, J. B., and Rupe, J. C. 1999. Compendium of Soybean Diseases, 4th ed. American Phytopathological Society, St. Paul, MN.

7. Hepperly, P. R., and Sinclair, J. B. 1978. Quality losses in Phomopsis-infected soybean seeds. Phytopathology 68:1684-1687.

8. Hobbs, T. W., Schmitthenner, A. F., and Kuter, G. A. 1985. A new Phomopsis species from soybean. Mycologia 77:535-544.

9. Jackson, E. W, Feng, C., Fenn, P, and Chen, P. 2009. Genetic mapping of resistance to Phomopsis seed decay in the soybean breeding line MO/PSD-0259 (PI562694) and plant introduction 80837. J. Hered. 100:777-783.

10. Jackson, E. W., Fenn, P, and Chen, P. 2005. Inheritance of resistance to Phomopsis seed decay in soybean PI 80837 and MO/PSD-0259 (PI 562694). Crop Sci. 45:2400-2404.

11. Li, S., Bradley, C. A., Hartman, G. L., and Pedersen, W. L. 2001. First report of Phomopsis longicolla from velvetleaf causing stem lesions on inoculated soybean and velvetleaf plants. Plant Dis. 85:1031.

12. Littell, R., Milliken, G., Stroup, W., Wolfinger, R., and Schabenberger, O. 2006. SAS for Mixed Models. SAS Press (http://www.sas. com/apps/pubscat/bookdetails.jsp?pc=59882).

13. Mengistu, A., Castlebury, L. A., Smith, J. R.,
Ray, J., and Bellaloui, N. 2009. Seasonal progress of Phomopsis longicolla infection on soybean plant parts and its relationship to seed quality. Plant Dis. 93:1009-1018.

14. Mengistu, A., Castlebury, L. A., Smith, J. R., Rossman, A. Y., and Reddy, K. N. 2007. Isolates of Diaporthe-Phomopsis from weeds and their effects on soybean. Can. J. Plant Pathol. 29:283-289

15. Mulik, M. M., and Sinclair, J. B.1999. Phomopsis Seed Decay. Pages 31-32 in: Compendium of Soybean Diseases. G. L. Hartman, J. B. Sinclair, and J. C. Rupe, eds. American Phytopathological Society, St. Paul, MN.

16. Pathan, M., S., Clark, K. M, Wrather, J. A., Sciumbato, G. L., Shannon, J. G., Nguyen, H. T., and Sleper, D. A. 2009. Registration of soybean germplasm SS93-6012 and SS936181 resistant to Phomopsis seed decay. J. Plant Regist. 3:91-93.

17. Roy, K. W., Keith, B. C., and Andrews, C. H. 1994. Resistance of hard seeded soybean lines to seed infection by Phomopsis, other fungi and soybean mosaic virus. Can. J. Plant Pathol. 16:122-128.

18. Roy, K. W., and Ratnayake, S. 1997. First report of Phomopsis longicolla infection of cowpea pods and seeds in Mississippi. Plant Dis. 81:693.

19. Rupe, J. C. 1990. Effects of temperature on the rate of infection of soybean seedlings by Phomopsis longicolla. Can. J. Plant Pathol. 12:4347.

20. Rupe, J. C., and Ferriss, R. S. 1986. Effects of pod moisture on soybean seed infection by Phomopsis sp. Phytopathology 76:273-277.

21. Shurtleff, M. C., and Averre, C. W. III. 1997. Glossary of Plant-Pathological Terms. American Phytopathological Society, St. Paul, MN.

22. Sinclair, J. B. 1993. Phomopsis seed decay of soybeans-a prototype for studying seed disease. Plant Dis. 77:329-334

23. Sinclair, J. B. 1999. Diaporthe-Phomopsis. Page 31 in: Compendium of Soybean Diseases. G. L. Hartman, J. B. Sinclair, and J. C. Rupe, eds. American Phytopathological Society, St. Paul, MN.

24. Vrandecic, K., Cosic, J., Riccion, L., Duvnjak, T., and Jurkovic, D. 2004. Phomopsis longicolla-new pathogen on Abutilon theophrasti in Croatia. Plant Pathol. 53:251. 
25. Wrather, J. A., and Koenning, S. R. 2009. Effects of diseases on soybean yields in the United States 1996 to 2007. Online. Plant Health Progress doi:10.1094/PHP-200904401-01-RS.

26. Wrather, J. A., Shannon, J. G., Stevens, W. E., Sleper, D. A., and Arelli, A. P. 2004. Soybean cultivar and fungicide effects on Phomopsis sp. seed infection. Plant Dis. 88:721-723.

27. Wrather, J. A., Sleper, D. A., Stevens, W. E., Shannon, J. G., and Wilson, R. F. 2002. Plant- ing data and cultivar effects on soybean yield, seed quality, and Phomopsis sp. seed infection. Plant Dis. 87:529-532.

28. Xue, A. G., Morrison, M. J., Cober, E., Anderson, T. R., Rioux, S., Ablett, G. R., Rajcan, I., Hall, R., and Zhang, J. X. 2007. Frequency of isolation of species of Diaporthe and Phomopsis from soybean plants in Ontario and benefits of seed treatments. Can. J. Plant Pathol. 29:354-364.

29. Zhang, A. W., Hartman, G. L., Riccioni, L.,
Chen, W. D., Ma, R. Z., and Pedersen, W. L. 1997. Using PCR to distinguish Diaporthe phaseolrum and Phomopsis longicolla from other soybean fungal pathogens to detect them in soybean tissue. Plant Dis. 81:1143-1149.

30. Zhang, A. W., Hartman, G. L., Riccioni, L., Pedersen, W. L., and Hartman, G. L., 1998. Molecular identification and phytogenetic grouping of Diaporthe phaseolrum and Pho mopsis longicolla isolates from soybean. Phytopathology 88:1306-1314. 